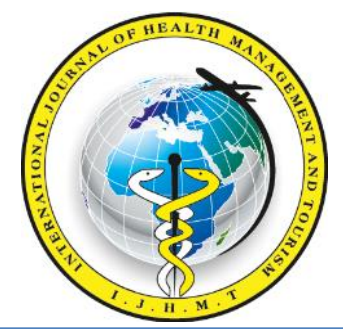

Internatıonal Journal Of Health Management And Tourism

\title{
EFFECTS OF THE URBAN IMAGE ON THE DESTINATION IMAGE IN HEALTH TOURISM: THE CASE OF SIVAS*
}

\section{Derya Fatma BİÇER ${ }^{1}$, Nurperihan TOSUN²*, Burak SAYAR ${ }^{3}$, Erkan SAĞLIK ${ }^{4}$}

${ }^{1}$ Assistant Professor, Department of Management and Organization, University of Cumhuriyet, Sivas

${ }^{2}$ Research Assistant, Department of Health Administration, University of Cumhuriyet, Sivas

${ }^{3}$ Graduate Student, Health Sciences Institute, University Of Cumhuriyet, Sivas

${ }^{4}$ Associate Professor, Department of Tourism Management, University of Cumhuriyet, Sivas

*E-mail: nkarabulut@cumhuriyet.edu.tr

\begin{abstract}
This study aims to determine the effects of urban image on destination image in terms of health tourism. The population of this research, which is designed as a descriptive and cross-sectional type, consists of people over 18 years of age living in Sivas province center. 387 people were included in the sample of the study, and 387 people were reached. Survey method was used as data collection tool. The questionnaire consists of three parts; urban image scale, destination image scale and questionnaire form designed to measure the introductory information of the participants. The data were evaluated using SPSS 21 statistical analyses, correlation and regression analyses. $51 \%$ of the participants are male, $33.1 \%$ are public employees, $58.7 \%$ have bachelor's degree and $19.9 \%$ have $1604-2000 €$ monthly income. $75.6 \%$ of the participants stated that they have gone to the thermal center before, and $43.6 \%$ reported that the purpose of the trip to the thermal resort was vacation. The perceptions of urban image and destination image of the participants were found to be above the average. According to the correlation analysis, there is a positively moderate correlation between urban image and destination image. The result of regression analysis is that the urban image influences the image of the region.
\end{abstract}

Key Words: Health tourism, urban image, destination image, Sivas

* This work was presented as oral presentation at the 8th International Health Tourism Congress on May 3-6, 2018, Kuşadası, Aydın. 


\section{Introduction}

Globally the tourism sector has an ongoing growth trend. According to a research conducted by United Nations World Tourism Organization in 2013, the number of international tourists, which was only 25 million in 1950, increase to 278 million in 30 years, to 528 million in 1995 and 1 billion 35 million in 2012, 1,235 million in 2016 and 1,322 million in 2017. Tourism barometer 2018 according to that study, it is projected that the number of tourists will reach 1 billion 800 million in 2030 (UNWTO, 2017; UNWTO, 2018).

United Nations World Tourism Organization (UNWTO) defined tourism in 2008 as "a social, cultural and economic phenomenon related to movements of people to other places than their normal domicile places". Health tourism is a type of tourism that provides sustainable added value to country economies and that has a great importance. Health tourism is a sector that enables growth of health organizations by using the international potential of movement for health purposes (SATURK, 2016). Increase in the health expenditures of countries, high costs, problems that arise from health systems, the fact that it is hard for the patient to reach service in his/her own country and waiting periods for treatment are long, development of mass communication tools, increase of means of transportation between countries, change of individual demands and expectations in the socio-cultural structure that changes with globalization, lead the global health tourism market to grow at international level (Çicek and Avderen, 2013).

Under the scope of "Thermal Tourism Cities Project" which has been launched by the Ministry of Culture and Tourism of the Republic of Turkey for developing Health and Thermal Tourism, the North Anatolian Thermal Tourism Cities Region (Sivas, Tokat, Amasya, Erzincan) is at the top among the regions with development priority.

According to 2014 Health Tourism Report prepared by TURSAB (Turkish Travel Agencies Union), the income per each patient who comes to Turkey for treatment purposes starts from 2 thousand USD, and this number may reach to 12 thousand USD in health tourism. Turkey targets an international patient number of 2 million and health tourism income of 20 billion USD for the year 2023 (TURSAB, 2014).

\section{Literature}

\section{Urban Image}

When we look at the studies in which the urban concepts such as urban, being civic and urban culture, are at the center, we see that there is no commonly accepted definition (Dasli, 2017: 58) According to this, a urban is defined a settlement place in economic terms where the nonagricultural production has intensified, division of work and specialization have increased depending on such economic characteristics, and where the level of interaction between individuals-groups, size and intensity of population increased (Bulut, 2017:16). 
The urban image is defined as the whole of beliefs comprising the impressions, opinions and thoughts about a urban. Kotler, Haider and Rein (1993) suggest that there exists six types of images by which a urban may define itself (Aydınoğlu, 2014).

The study conducted by Firat and Komurcuoglu (2015) on the Students of Mugla Sitki Kocman University for Mugla Urban Brand and Image Perception, suggested that Mugla urban was expensive, quite, safe and outward, and among the characteristics of Mugla urban image were the tourism areas, ancient Mugla houses, and its brand benefits were the natural attractions, its university and historical heritage (Frrat and Kömürcüoğlu, 2015).

\section{Destination Image}

Destination's image has been the subject of considerable research during the last three decades. There are many possible approaches to studying destination image these are anthropology sociology, geography, semiotics, human behavior and marketing. Destination's image has significance of the role played in the process of decision making and choice. Destination's image is universally acknowledged, since it affects the individual's subjective perception and consequent behavior (Gallarza et al., 2002; Beerli and Martín, 2004). The word "imaj" was defined as the "image" in Turkish Language Institution dictionary. In Oxford dictionary, it is defined as "representation of a person or an object with its exterior characteristics." The destination could be defined as "a place that has various attractions, characteristics and natural beauties, presented to the service of tourists", "a geographical region that provides multipurpose, multi-scope and multi-dimensional tourism products for those who travel for tourism purposes (Ceylan, 2011). Measurement of the perceptions of destinations has been a important theme in the early 1970s and most popular theme within the destination marketing literature (Pike and Page, 2014).

\section{Method}

The objective of this study is to identify the effect of thermal urban image to the destination image on the basis of Sivas province sample. The universe and the sample of the study comprise the central population of Sivas province. According to the results of population registry system, the total population of central Sivas province in 2017 is 372.300. Simple random sampling method was chosen among the improbable sampling methods in the study. For $\alpha=0,05, H=$ $\pm 0,05$ and rates $\mathrm{p}=0,5$ ve $\mathrm{q}=0,5$ the sample size was calculated as 384 people (Ural and K1liç, 2011).

The date of the study, which is constructed as descriptive and cross-sectional type, was collected with survey method. The survey method comprises three sections. The first section includes a urban image scale comprising 79 questions and 14 sub-dimensions in order to measure the urban image. This scale as been developed by Martinez and Garcia (2007) and applied to Erzurum sample by Selçuk et al (2010). Questions in the second section are directed towards measuring the destination image, comprising 17 questions. This scale was taken from Timur's (2015) study. The third section includes 9 questions prepared using the relevant literature in order to identify the descriptive characteristics of the participants. Data was applied with face 
to face interview method by obtaining the verbal consents of the participants by the researchers themselves.

The research model under the scope of the research is as follows

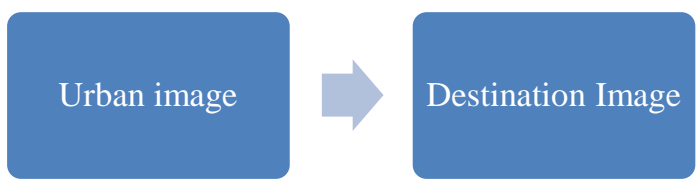

Hypothesis developed under the scope of research model are indicated as follows.

$\mathrm{H} 1$ : There is a statistically significant relationship between the urban image and the destination image.

$\mathrm{H} 2$ : Urban image affects destination image.

The Cronbach Alpha reliability coefficient of the study is 0,957. The data was evaluated using descriptive statistics in SPSS 21 software, and Spearman's Rho Correlation and regressions analysis. Whether the data was distributed normally was assessed with Kolmogorov -Simirnov and was found to be $p>0.05$. The data has normal distribution with a reliability of $95 \%$ for all groups.

\section{Findings}

Table 1. Distribution of Socio-Demographic Characteristics of the Participants

\begin{tabular}{|c|c|c|}
\hline Gender & $n$ & Percentage (\%) \\
\hline Female & 200 & 51,7 \\
\hline Male & 187 & 48,3 \\
\hline Total & 387 & 100,0 \\
\hline Age & $\mathbf{n}$ & Percentage (\%) \\
\hline $20-30$ & 161 & 41,9 \\
\hline $31-40$ & 100 & 26,0 \\
\hline $41-50$ & 100 & 26,0 \\
\hline $51-60$ & 20 & 5,2 \\
\hline More than 61 & 3 & 8 \\
\hline Total & 384 & 100,0 \\
\hline Monthly İncome & $\mathbf{n}$ & Percentage (\%) \\
\hline Less than 1604 & 21 & 5,4 \\
\hline 1604- 2000 & 77 & 19,9 \\
\hline $2001-2500$ & 35 & 9,0 \\
\hline $2501-3000$ & 52 & 13,4 \\
\hline $3001-3500$ & 35 & 9,0 \\
\hline $3501-4000$ & 38 & 9,8 \\
\hline $4001-4500$ & 59 & 15,2 \\
\hline $4501-5000$ & 17 & 4,4 \\
\hline More than 5001 & 53 & 13,7 \\
\hline Total & 387 & 100,0 \\
\hline
\end{tabular}




\begin{tabular}{|c|c|c|}
\hline Job & $\mathbf{n}$ & Percentage (\%) \\
\hline Housewife & 30 & 7,8 \\
\hline Self-employment & 61 & 15,8 \\
\hline Other & 44 & 11,4 \\
\hline Public & 128 & 33,1 \\
\hline Unemployed & 19 & 4,9 \\
\hline Retired & 14 & 3,6 \\
\hline Artisan & 91 & 23,5 \\
\hline Total & 387 & 100,0 \\
\hline Education status & $\mathbf{n}$ & Percentage (\%) \\
\hline Literate & 5 & 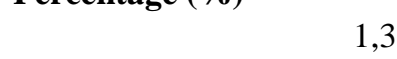 \\
\hline Primary Education & 20 & 5,2 \\
\hline High School & 85 & 22,0 \\
\hline License & 227 & 58,8 \\
\hline Graduate & 49 & 12,7 \\
\hline Total & 386 & 100,0 \\
\hline \multicolumn{3}{|l|}{ Visit to termal center } \\
\hline Yes & 292 & $\mathbf{7 5 , 6}$ \\
\hline No & 94 & 24,4 \\
\hline Total & 386 & 100,0 \\
\hline Aim of termal center & $\mathbf{n}$ & Percentage $(\%)$ \\
\hline Holiday & 149 & 43,6 \\
\hline Health And Treatment & 75 & 21,9 \\
\hline Entertainment & 116 & 33,9 \\
\hline Holiday / Health And Treatment & 2 & ,6 \\
\hline Total & 342 & 100,0 \\
\hline Visit to termal center other than Sivas & $\mathbf{n}$ & Percentage (\%) \\
\hline Yozgat & 60 & 15,2 \\
\hline Nevşehir Kozaklı & 88 & 22,2 \\
\hline Afyon Kaplıcaları & 37 & 9,3 \\
\hline Bursa & 22 & 5,6 \\
\hline Denizli & 17 & 4,3 \\
\hline Ankara- Kızılcahamam & 37 & 9,3 \\
\hline Other & 135 & 34,1 \\
\hline Total & 396 & 100,0 \\
\hline Number of Departure to Thermal Center & $\mathbf{n}$ & Percentage (\%) \\
\hline $1-3$ & 139 & 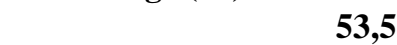 \\
\hline 4-6 & 70 & 26,9 \\
\hline More than 7 & 51 & 19,6 \\
\hline Total & 260 & 100,0 \\
\hline
\end{tabular}

When the demographic distributions of people participating in the research were studied, it was found that $51.7 \%$ were male and 48.3 were female. $41.9 \%$ of the participants are in $20-30$ age group, and $19.9 \%$ have an income between $1604-2000$ TL, 33.1\% were public workers and $58.8 \%$ had undergraduate education. When the status of participants going to a thermal center was examined, it was found that $75.6 \%$ of them went to the thermal center and $43.6 \%$ were visiting the thermal center of vacation purposes. When the thermal centers visited outside Sivas were examined, $22.2 \%$ of the participants stated they went to Nevsehir Kozakli and 34.1\% stated they visited other thermal centers and the frequency of visiting thermal center was indicated to be $1-3$ by $53.5 \%$ of them (Table 1 ). 
Table 2: Distribution Of Overall Score Averages of Urban Image Scales

\begin{tabular}{lccccc}
\hline & N & MiN & MAX & $\bar{X}$ & S.S. \\
\hline Architecture and Urban Attraction & 383 & 1,00 & 5,00 & 2,74 & 0,90 \\
\hline Transport, Traffic and Communication & 385 & 1,00 & 4,71 & 2,98 & 0,59 \\
\hline Historical heritage & 382 & 1,00 & 5,00 & 3,63 & 0,94 \\
\hline Environment & 374 & 1,00 & 5,00 & 2,75 & 0,65 \\
\hline Social Problem & 358 & 1,00 & 7,43 & 3,19 & 0,80 \\
\hline Culture & 380 & 1,00 & 5,00 & 2,62 & 0,85 \\
\hline Innovation and business culture & 375 & 1,00 & 5,00 & 2,52 & 0,82 \\
\hline Economy and Trade & 377 & 1,00 & 7,75 & 3,32 & 0,71 \\
\hline Service Range & 359 & 1,00 & 5,00 & 2,72 & 0,92 \\
\hline University Education & 370 & 1,00 & 8,67 & 2,91 & 1,14 \\
\hline International Projection & 376 & 1,00 & 5,00 & 2,24 & 0,91 \\
\hline Citizens' self perception & 381 & 1,00 & 5,00 & 2,49 & 0,97 \\
\hline Urban general (living) image & 376 & 1,00 & 5,00 & 2,74 & 1,04 \\
\hline Satisfaction and pride & 377 & 1,00 & 5,00 & 2,82 & 1,21 \\
\hline Overall the Urban image & $\mathbf{2 8 0}$ & $\mathbf{1 , 0 0}$ & $\mathbf{4 , 7 3}$ & $\mathbf{2 , 8 3}$ & $\mathbf{0 , 5 5}$ \\
\hline Overall the Destination Image & $\mathbf{3 6 5}$ & $\mathbf{1 , 0 0}$ & $\mathbf{5 , 0 0}$ & $\mathbf{2 , 8 1}$ & $\mathbf{0 , 7 8}$ \\
\hline
\end{tabular}

Table 2 gives definitive statistical results for the urban image scale and its sub-dimensions. The average points received overall the urban image scale was $2,83 \pm 0,55$, and the average points received from destination image scale was $2,81 \pm 0,78$. When the average points given for urban image scale sub-dimensions were examined; architectural and urban attraction sub-dimension average point was found as $2,74 \pm 0,90$, transportation, traffic and communication subdimension average point was found as $2,98 \pm 0,59$, historical heritage sub-dimension average point was found as $3,63 \pm 0,94$, environment sub-dimension average point was found as $2,75 \pm$ 0,65 , social problem sub-dimension average point was found as $3,19 \pm 0,80$, culture subdimension average point was found as $2,62 \pm 0,85$, innovation and business culture subdimension average point was found as $2,52 \pm 0,82$, economy and trade sub-dimension average point was found as $3,32 \pm 0,71$, service range sub-dimension average point was found as $2,72 \pm 0,92$, university education sub-dimension average point was found as $2,91 \pm 1,14$, international projection sub-dimension average point was found as $2,24 \pm 0,91$, citizens' self perception sub-dimension average point was found as 2,49 $\pm 0,97$, urban general (living) image sub-dimension average point was found as $2,74 \pm 1,04$, satisfaction and pride sub-dimension average point was found as $2,82 \pm 1,21$ (Table 2). 
Table 3: Results of Spearman's Rho Correlation Analysis for Determining the Relation Between the Urban Image Scale and the Lower Dimensions and the Destination Image

\begin{tabular}{|c|c|c|c|c|c|c|c|c|c|c|c|c|c|c|c|c|}
\hline & 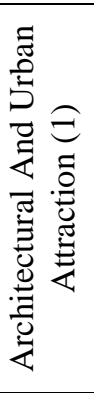 & 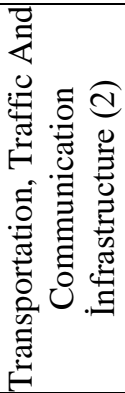 & 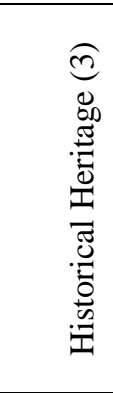 & 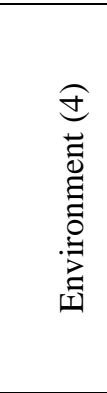 & 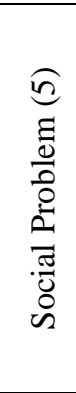 & 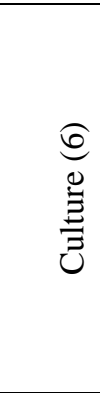 & 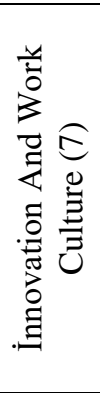 & 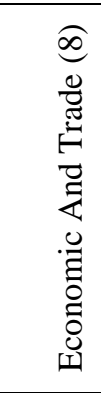 & 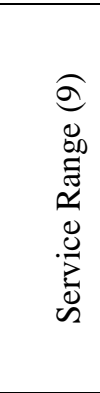 & 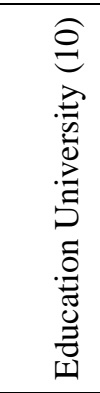 & 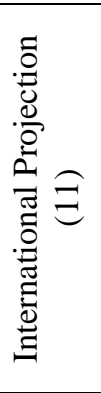 & 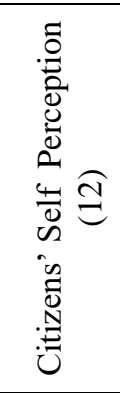 & 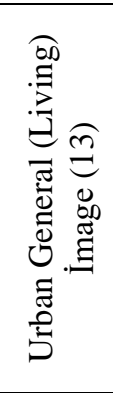 & 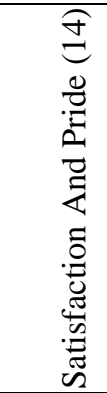 & 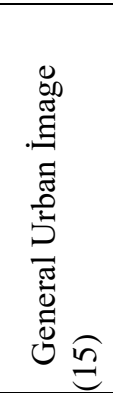 & 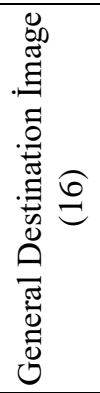 \\
\hline \multirow[t]{2}{*}{1} & 1 &, $458^{* *}$ &, $407^{* *}$ &, $314^{* *}$ & $\begin{array}{c}- \\
.065\end{array}$ &, $577^{* *}$ &, $459^{* *}$ &, $395^{* *}$ &, $464^{* *}$ &, $403^{* *}$ &, $381^{* *}$ &, $313^{* *}$ &, $405^{* *}$ &, $469^{* *}$ &, $\mathbf{7 3 5}^{* *}$ &, $401^{* * *}$ \\
\hline & . & ,000 & ,000 & ,000 &, 224 & ,000 & ,000 & ,000 & ,000 & , 000 & , 000 &, 000 & ,000 & ,000 & ,000 & ,000 \\
\hline \multirow[t]{2}{*}{2} & & 1 &, $309^{* *}$ &, $389^{* *}$ &, 028 &, $502^{* *}$ &, $398^{* *}$ &, $300^{* *}$ &, $432^{* *}$ &, $440^{* *}$ & $416^{* *}$ &, $301^{* *}$ &, $370^{* *}$ &, $402^{* *}$ &, $634^{* * *}$ &, $435^{* *}$ \\
\hline & & . & ,000 & ,000 & ,594 & ,000 & ,000 & ,000 & ,000 & ,000 &, 000 & ,000 & ,000 & ,000 & ,000 & ,000 \\
\hline \multirow[t]{2}{*}{3} & & & 1 & $356^{* * *}$ & ,048 &, $362^{* *}$ & $451^{* * *}$ & $410^{* *}$ &, $345^{* *}$ &, $360^{* *}$ & $251^{* *}$ &, $361^{* *}$ &, $376^{* *}$ &, $427^{* *}$ &, $571^{* *}$ &, $\mathbf{3 8 3}^{* * *}$ \\
\hline & & & . & ,000 &, 365 & ,000 & ,000 &, 000 &, 000 & ,000 & ,000 & ,000 &, 000 & ,000 &, 000 & ,000 \\
\hline \multirow[t]{2}{*}{4} & & & & 1 &, 116 &, $369^{* *}$ &, $386^{* *}$ &, $296^{* *}$ &, $213^{* *}$ &, $248^{* *}$ &, $257^{* *}$ &, $281^{* *}$ &, $258^{* *}$ &, $239^{* *}$ & ,498** &, $344^{* *}$ \\
\hline & & & & . & ,029 & ,000 & ,000 & ,000 &, 000 & ,000 & ,000 & ,000 & ,000 & ,000 & ,000 & ,000 \\
\hline \multirow[t]{2}{*}{5} & & & & & 1 &,- 050 &,$- 111^{*}$ &, 060 & $\begin{array}{c}- \\
192^{* *} \\
\end{array}$ &,$- 130^{*}$ &,- 077 &,$- 154^{* *}$ &,$- 109^{*}$ & $\begin{array}{c}- \\
, 167^{* *}\end{array}$ &,- 032 &,- 086 \\
\hline & & & & & . & ,346 & ,039 & ,264 & ,000 & ,016 & ,148 & ,004 & ,043 & ,002 & ,589 &, 113 \\
\hline \multirow[t]{2}{*}{6} & & & & & & 1 & $477^{* *}$ &, $421^{* *}$ &, $516^{* *}$ &, $487^{* *}$ & $428^{* * *}$ &, $309^{* *}$ &, $338^{* *}$ &, $381^{* *}$ &, $\mathbf{7 0 8}^{* *}$ &, $429^{* *}$ \\
\hline & & & & & & . & ,000 & ,000 & ,000 & ,000 & ,000 & ,000 &, 000 & ,000 &, 000 & ,000 \\
\hline \multirow[t]{2}{*}{7} & & & & & & & 1 &, $359^{* *}$ &, $509^{* *}$ &, $587^{* *}$ & $486^{* *}$ &, $523^{* *}$ & $394^{* *}$ & $496^{* *}$ & ,753 ${ }^{* * *}$ &, $\mathbf{5 0 3}^{* * *}$ \\
\hline & & & & & & & . &, 000 & ,000 & ,000 & ,000 & ,000 &, 000 &, 000 &, 000 & ,000 \\
\hline 8 & & & & & & & & 1 &, $384^{* *}$ &, $329^{* * *}$ &, $258^{* * *}$ &, $306^{* *}$ &, $344^{* *}$ &, $311^{* *}$ &, $\mathbf{5 3 0}^{* *}$ &, $\mathbf{3 8 6}^{* *}$ \\
\hline
\end{tabular}




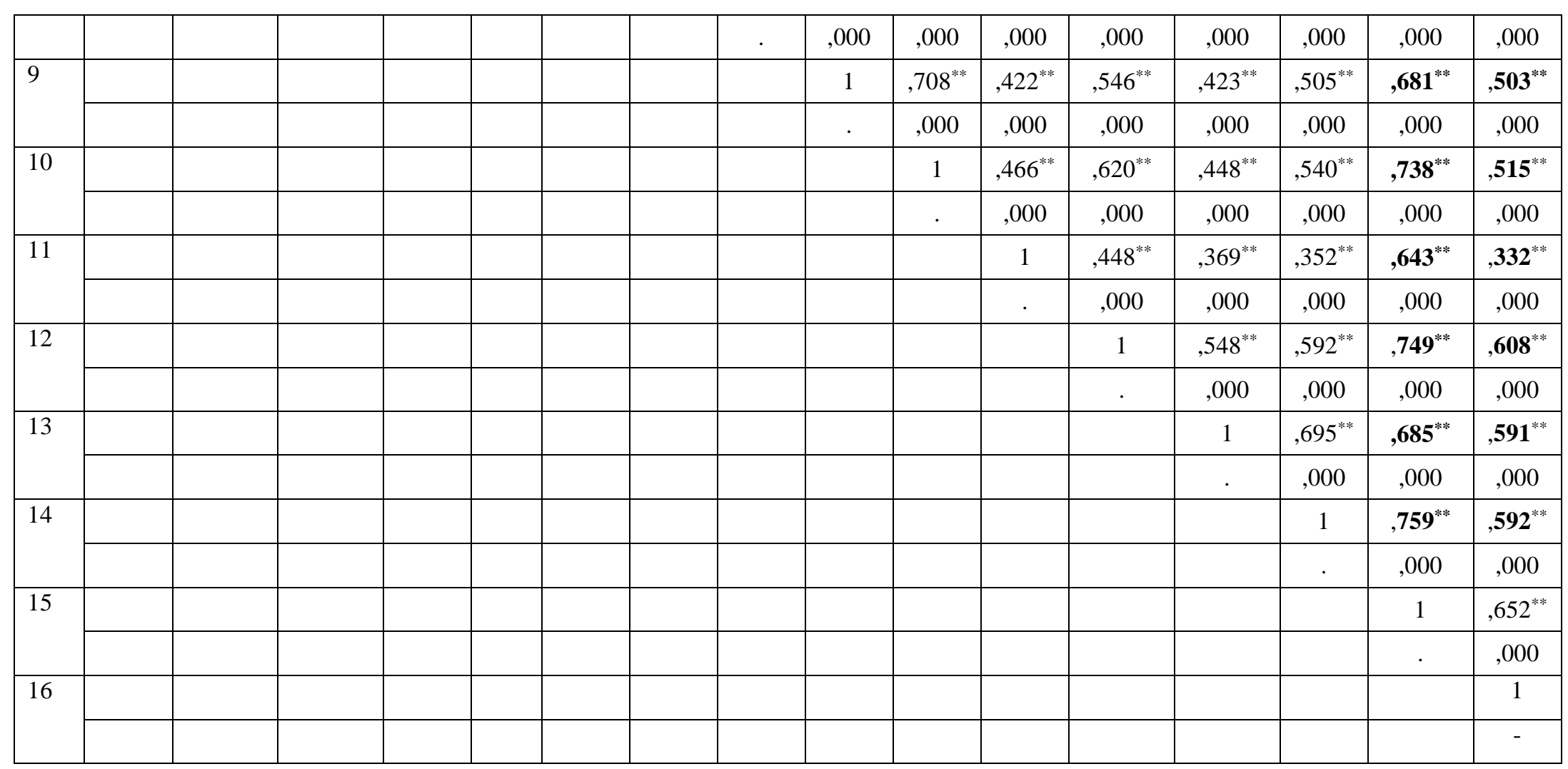


Table 3 gives the results of correlation analysis conducted for determining the relationship between urban image scale and sub-dimensions and the destination image. A statistically significant relationship in positive direction was determined with a correlation of coefficient of 0.652 between general destination image and the. This being the case, H1 hypothesis was accepted. When the relationships between destination image and sub-dimensions of urban image; a statistically significant relationship in positive direction was determined with a correlation coefficient of 0.401 with architectural and urban attraction sub-dimension, with a correlation coefficient of 0.435 with transportation, traffic and communication infrastructure, with a correlation coefficient of 0.383 , with historical heritage sub-dimension, with a correlation coefficient of 0.344 , with environment sub-dimension, with a correlation coefficient of 0.503 , with culture sub-dimension, with a correlation coefficient of 0.503 , with innovation and work culture sub-dimension, with a correlation coefficient of 0.386 with economic and trade sub-dimension, with a correlation coefficient of 0.503 , with service range sub-dimension, with a correlation coefficient of 0.515 , with education university subdimension, with a correlation coefficient of 0.332 , with international projection subdimension, with a correlation coefficient of 0.608 , with citizens' self-perception subdimension, with a correlation coefficient of 0.591 with urban general (living) image subdimension, with a correlation coefficient of 0.592 , with international projection sub-dimension.

Table 4: Results of Regression Analysis for Testing the Effect of Urban Image on the Destination Image

\begin{tabular}{lccccccc}
\hline & B & $\mathbf{t}$ & $\mathbf{P}$ & $\mathbf{R}^{\mathbf{2}}$ & $\begin{array}{c}\text { Adjusted } \\
\mathbf{R} \\
\text { Square }\end{array}$ & F & $\begin{array}{c}\text { Significancy } \\
\mathbf{F}\end{array}$ \\
\hline Constant & 0,151 & 0,735 & 0,463 & 0,403 & 0,401 & 178,138 & $0,000^{*}$ \\
\hline Urban Image & 0,635 & 13,347 & $0,000^{*}$ & & & &
\end{tabular}

$* \mathrm{P}<0,05$

When the results of regression analysis were examined: It could be seen that the urban image has a significant impact on the destination image. It was found out that the urban image has a positive impact on the destination image at a rate of $40.1 \%$ (with a significance level of 0.05). The regression model is as follows. H2 Hypothesis has been accepted (Table 4).

Destination Image $=0,635^{*}$ Urban Image. 
Table 5: Regression Analysis Related To Effect Of Urban Image On The Destination Image

\begin{tabular}{|c|c|c|c|c|c|c|c|}
\hline & B & $\mathbf{t}$ & $\mathbf{P}$ & $\mathbf{R}^{2}$ & $\begin{array}{l}\text { Adjusted } \\
\text { R Square }\end{array}$ & $\mathbf{F}$ & $\begin{array}{l}\text { Significancy } \\
\text { F }\end{array}$ \\
\hline Constant & 873 & 3,134 &, $002 *$ & \multirow{15}{*}{0,552} & \multirow{15}{*}{0,527} & \multirow{15}{*}{22,062} & \multirow{15}{*}{$0,000^{*}$} \\
\hline $\begin{array}{l}\text { Architecture and } \\
\text { Urban Attraction }\end{array}$ &,- 022 &,- 342 &, 732 & & & & \\
\hline $\begin{array}{l}\text { Transport, Traffic and } \\
\text { Communication }\end{array}$ & ,104 & 1,894 &, 059 & & & & \\
\hline Historical heritage &,- 015 &,- 271 &, 786 & & & & \\
\hline Environment &,- 001 &,- 011 & ,991 & & & & \\
\hline Social Problem &,- 009 &,- 193 & 847 & & & & \\
\hline Culture &, 111 & 1,770 & ,078 & & & & \\
\hline $\begin{array}{l}\text { Innovation and } \\
\text { business culture }\end{array}$ &, 022 & ,340 & ,734 & & & & \\
\hline Economy and Trade &,- 039 &,- 796 &, 427 & & & & \\
\hline Service Range & ,005 & 077 & ,939 & & & & \\
\hline University Education &, 050 &, 700 &, 485 & & & & \\
\hline $\begin{array}{l}\text { International } \\
\text { Projection }\end{array}$ &,- 068 & $-1,205$ & ,229 & & & & \\
\hline $\begin{array}{l}\text { Citizens' self } \\
\text { perception }\end{array}$ &, 305 & 4,200 &, $000 *$ & & & & \\
\hline $\begin{array}{l}\text { Urban general } \\
\text { (living) image }\end{array}$ & ,290 & 4,312 &, $000^{*}$ & & & & \\
\hline Satisfaction and pride &, 128 & 1,713 & 088 & & & & \\
\hline
\end{tabular}

When the results of regression analysis were examined: It was seen that the self-perception of the citizens has a significant impact on the urban general (living) image destination. It was seen that the self-perception of the citizens has a significant impact on the urban general (living) image destination in positive direction at a rate of \% 52.7 (with a significance level of 0.05 ) (Table 5). The regression model is as follows.

Destination image $=0,873+0,305^{*}$ Citizen's Self-Perception $+0,290 *$ Urban General (Living) Image 


\section{Conclusion And Recommendations}

Health tourism is one of the important sectors that has high added value. In order for the countries to have competitive advantage in the international market and become successful in the field of health tourism, they need to create brand value and generate a positive destination image. Urban image and destination image are important concepts for the health tourists to prefer their destinations.

The purpose of this study is to identify the impacts of urban image on the destination image from the point of view of health tourism. The study was conducted on people living in Sivas provincial center. $51.7 \%$ of the participants are male, $33.1 \%$ are public workers, $58.7 \%$ are undergraduates and $19.9 \%$ have an income between 1604-2000 $₹ 75.5 \%$ of the participants stated that they went to a thermal center and $38.5 \%$ indicated that their purpose of visit to the thermal was vacation. The average points received overall the urban image scale was $2,83 \pm 0,55$, and the average points received from destination image scale was $2,81 \pm 0,78$. In line with these findings, the urban image of Sivas province was found to be above the average, and the image of health tourism destinations for Sivas province was also found to be above the average. As a result of the correlation analysis, there is a positive ( $\mathrm{r}=$ 0.652 ) relation between urban image and destination image. It could be seen that the urban image has a significant impact on the destination image. It was found out that the urban image has a positive impact on the destination image at a rate of $40.1 \%$. As a conclusion, it could be said that the urban image and destination image of participants were above the average. The higher the urban image perception is, the more the destination image increases at medium level.

In order for Sivas province to become a preferable center in health tourism, it is recommended that activities be carried out towards increasing the urban image in positive direction, that promotion and marketing activities be increased in the target countries and regions, and public and private sectors collaborations be improved in the field of marketing.

\section{References}

Aydınlığlu, Ö. (2014). Kent İmajı Ve Kent İmajının Ölçümü: Kahramanmaraş Kenti İmajı Üzerine Bir Araştırma'. Atatürk Üniversitesi Sosyal Bilimler Enstitüsü. Yüksek Lisans Tezi. Erzurum.

Beerli, A., Martín J. D. (2004) "Factors influencing destination image”. Annals of Tourism Research 31(3): 657-681.

Bulut, E. (2017). “Temel Kavramlar”, Editör: Mustafa Talas ve Emin Yiğit, Kent Sosyolojisi, Lisans Yayınc1l1k, İstanbul, s. 11-32.

Ceylan, S.(2011). “Destinasyon Marka İmajı ve Pamukkale Yöresinde Bir Uygulama”. Uluslararası İktisadi ve İdari İncelemeler Dergisi.4(7):89-102

Çiçek, R, Avderen, S. (2013) “Sağlık Turizmi Açısından İç Anadolu Bölgesi'ndeki Kaplıca ve Termal Tesislerin Mevcut Yapısının ve Potansiyelinin Belirlenmesine Yönelik Bir Araştırma', KMÜ Sosyal ve Ekonomik Araştırmalar Dergisi 15 (25): 25-35.

Daşlı, Y. (2017). “Türk Toplumlarında İslamiyet Öncesi ve İslamiyet Sonrası Kent”, Editör: Mustafa Talas ve Emin Yiğit, 1, s.318.

Fırat, A. Kömürcüoğlu, F.(2015). "Muğla Şehir Markası ve İmaj Algısı; Muğla Sitkı Koçman Üniversitesi Öğrencileri Üzerine Bir Alan Araştırması.' Y Ÿnetim Bilimleri Dergisi. 26(13):285-304. 
Internet: http://dosyamerkez.saglik.gov.tr/Eklenti/10949,07pdf.pdf?0 (22.03.2018)

Internet: http://yigm.kulturturizm.gov.tr/TR,11475/genel-tanimlar.html (22.03.2018)

Gallarza, M. G., Saura, I. G., \& Garcia, H. C. (2002). Destination image - towards a conceptual framework. Annals of Tourism Research, 29(1), 56-78.

Oğurlu, İ.(2014). "Çevre, Kent İmajı, Kent Kimliği, Kent Kültürü Etkileşimlerine Bir Bakış'. İstanbul Ticaret Üniversitesi Fen Bilimleri Dergisi. 13(26):275-293.

Pike, S., Page, S. (2014). "Destination marketing organizations and destination marketing: A narrative analysis of the literatüre". Tourism Management, 41, 202-227.

SATÜRK 2016 Raporu, http://www.saturk.gov.tr/images/pdf/tyst/02.pdf (22.03.2018).

Timur, B.(2015). “Termal Turizmde Hizmet Kalitesi, Algılanan Destinasyon İmaj1 Ve Tekrar Ziyaret Niyeti Arasındaki İlişkilerin İncelenmesi', Eskişehir Osmangazi Üniversitesi Sosyal Bilimler Enstitüsü Yüksek Lisans Tezi, Eskişehir.

TC. Kültür ve Turizm Bakanlığı (2007). “Türkiye Turizm Stratejisi 2023 EylemPlanı” 2007-2013, http://www.kultur.gov.tr/Eklenti/906,ttstratejisi2023pdf.pdf?0 (22.03.2018).

Tengilimoğlu, D. (2017), Sağlık Turizmi, 2.Baskı, Siyasal Yayınevi, Ankara.

TÜRSAB 2014 Sağlik Turizmi Raporu, https://www.tursab.org.tr/dosya/11430/saglikturizmiraporu_11430_3841225.pdf (20.03.2018)

UNWTO, World Tourism Barometer (2018). (08.08.2018)

UNWTO, Tourism Highlights 2017 Edition. (08.08.2018)

Ural, A., Kılıç, İ. (2011).Bilimsel Araştırma Süreci ve SPSS ile Veri Analizi, 3.Baskı, Detay Yayınc1lık Ankara. 